\title{
TITLE:
}

\section{THE PACIFIC RIDLEY TURTLE IN JAPANESE AND ADJACENT WATERS}

$\operatorname{AUTHOR}(\mathrm{S})$ :

Nishimura, Saburo; Shirai, Kazuo; Tatsuki, Takeshi; Sugihara, Chiyota

\section{CITATION:}

Nishimura, Saburo ...[et al]. THE PACIFIC RIDLEY TURTLE IN JAPANESE AND ADJACENT WATERS. PUBLICATIONS OF THE SETO MARINE BIOLOGICAL LABORATORY 1972, 19(6): 415-426

ISSUE DATE:

1972-03-31

URL:

http://hdl.handle.net/2433/175736

RIGHT: 


\title{
THE PACIFIC RIDLEY TURTLE IN JAPANESE AND ADJACENT WATERS ${ }^{1)}$
}

\author{
SABURo NISHIMURA ${ }^{2)}$, KAzUo SHIRAI ${ }^{3)}$, TAKESHI TATSUKI ${ }^{4}$ \\ and ChIYota SUGIHARA ${ }^{53}$
}

With 8 Text-figures

Until recently taxonomy of sea turtles of the tribe Carettini ZANGERL, 1958 of the family Cheloniidae had been much confused in Japan and the western Pacific countries. It was in 1967 that Caretta caretta (L.), the loggerhead turtle, and Lepidochelys olivacea (Eschscholtz), the Pacific ridley turtle, the two species of the tribe appearing in the Japanese waters, were rightly discriminated and their occurrences around Japan were recorded separately for the first time (Nishimura \& Hara 1967). Prior to that date, the two species were either lumped together or mistaken for each other. It was revealed by Nishimura \& Hara (op. cit.) that the loggerhead turtle was common around Japan and constituted a unique sea turtle population that nested on its southern coasts, while the Pacific ridley turtle was seemingly rare, only two definite records of occurrence being known throughout the Japanese Islands to that time.

Since the publication of the above-mentioned paper, the first author and his collaborators have been very earnestly searching for any records of occurrence of the Pacific ridley turtle in order to clear the distribution pattern of this species in the western Pacific, and up to now some further records have been gathered in their hands. Thus, the present paper is a compilation of all these records and at the same time is prepared to discuss on the recent status of this sea turtle in Japanese and adjacent waters together with some biological considerations.

Acknowledgments-The authors wish to extend their cordial thanks to Mr. T. Nirya of the Izutsu Fishing Co., Nagasaki, to the officers of the Nagasaki Branch of the Taiyo Fishing Co,, and to Mr. I. SATo in Sakata for their kindness to donate the specimens or to permit to examine the specimens, and for pertinent data. Dr. S. Mrro of the Naikai Regional Fisheries Research Laboratory (now at the Asian Fisheries Development Center, Singapore) and Messrs. Ch. Araga and H. Tanase of the Seto Marine Biological Laboratory willingly furnished valuable information and assistance. Dr. T. TokıokA of the

1) Contributions from the Seto Marine Biological Laboratory, No. 561, and Contributions from the Sabiura Marine Park Research Station, No. 1.

2) Seto Marine Biological Laboratory, Sirahama.

3) Nagasaki Aquarium, Nagasaki.

4) Sabiura Marine Park Research Station, Kushimoto.

5) 18 Sakaye-cho, Sakata, Yamagata Prefecture.

Publ. Seto Mar. Biol. Lab., XIX (6), 415-426, 1972. (Article 27) 
Seto Marine Biological Laboratory kindly read and improved the manuscript and Mr. S. SATAKE in Sakata offered important photographs. To all these gentlemen the authors' heartfelt thanks are due.

\section{Occurrences in Japanese and Adjacent Waters, with Some Biological Notes}

The records of occurrence of the Pacific ridley turtle in Japanese and adjacent waters known to the present authors till now, including the previously reported two (Nishimura \& Hara 1967), are compiled in Table 1, and their geographic positions are shown on the map in Fig. 1.

These records are classified by areas and seasons in Table 2. In this table two interesting points may be seen. The first is that the East China Sea and its immediate adjoining waters yield a decidedly larger number of records than any coasts of Japanese

Table 1. Records of the Pacific ridley turtle in Japanese and adjacent waters, 1957-1971.

\begin{tabular}{|c|c|c|c|}
\hline No. & Date & Locality & Remarks \& Source \\
\hline 1 & Autumn, 1957 & $\begin{array}{l}\text { Shikanoshima, northwest } \\
\text { Kyushu }\end{array}$ & $\begin{array}{l}\text { Entangled in a set net. Carapace } \\
\text { length } 45 \mathrm{~cm} \text {. (Nishimura \& } \\
\text { HaRA } 1967 \text { ) }\end{array}$ \\
\hline $2 *$ & Summer, 1958 & $\begin{array}{l}\text { East China Sea } \\
\quad \text { (Exact locality unknown) }\end{array}$ & Entangled in a trawl net \\
\hline $3 *$ & Autumn, 1958 & $\begin{array}{l}\text { East China Sea } \\
\quad \text { (Exact locality unknown) }\end{array}$ & Entangled in a trawl net \\
\hline 4 & December, 1961 & $\begin{array}{l}\text { Teradomari, Niigata } \\
\text { Pref. }\end{array}$ & $\begin{array}{l}\text { Stranded ashore. Carapace length } \\
62 \mathrm{~cm} \text {. (Nishimura \& HarA } \\
1967 \text { ) }\end{array}$ \\
\hline $5^{*}$ & Sept. 26, 1967 & $\begin{array}{l}\text { Off Yamato-mura, Amami } \\
\text { Oshima, Kagoshima Pref. }\end{array}$ & Caught at sea surface \\
\hline $6 *$ & Jan. 3, 1968 & $\begin{array}{l}\text { Miyanoura, Sakata, } \\
\text { Yamagata Pref. }\end{array}$ & Stranded ashore \\
\hline $7 *$ & Aug. 28, 1969 & $\begin{array}{l}\text { East China Sea } \\
\quad\left(31^{\circ} 20^{\prime} \mathrm{N}, 125^{\circ} 10^{\prime} \mathrm{E}\right)\end{array}$ & Entangled in a trawl net \\
\hline $8 *$ & Sept. 8,1969 & $\begin{array}{l}\text { East China Sea } \\
\quad\left(30^{\circ} 20^{\prime} \mathrm{N}, 124^{\circ} 45^{\prime} \mathrm{E}\right)\end{array}$ & Entangled in a trawl net \\
\hline $9 *$ & Sept. 8, 1971 & $\begin{array}{l}\text { East China Sea } \\
\quad\left(27^{\circ} 49^{\prime} \mathrm{N}, 122^{\circ} 20^{\prime} \mathrm{E}\right)\end{array}$ & Entangled in a trawl net \\
\hline $10^{*}$ & Oct. 11,1971 & $\begin{array}{l}\text { Within } 1 \mathrm{~km} \text { off } \\
\text { Shiono-misaki, Wakayama } \\
\text { Pref. }\end{array}$ & $\begin{array}{l}\text { Entangled in a drift gill-net } \\
\text { for flyingfish }\end{array}$ \\
\hline $11 *$ & Nov. 5, 1971 & $\begin{array}{l}\text { Within } 1 \mathrm{~km} \text { off } \\
\text { Shiono-misaki, Wakayama } \\
\text { Pref. }\end{array}$ & $\begin{array}{l}\text { Entangled in a drift gill-net } \\
\text { for flyingfish }\end{array}$ \\
\hline $12 *$ & Dec. 8,1971 & $\begin{array}{l}\text { East Ghina Sea } \\
\quad\left(28^{\circ} 11^{\prime} \mathrm{N}, 124^{\circ} 18^{\prime} \mathrm{E}\right)\end{array}$ & Entangled in a trawl net \\
\hline $13^{*}$ & Dec. 11,1971 & $\begin{array}{l}\text { East China Sea } \\
\quad\left(31^{\circ} 30^{\prime} \mathrm{N}, 126^{\circ} 41^{\prime} \mathrm{E}\right)\end{array}$ & Entangled in a trawl net \\
\hline
\end{tabular}

* New records. Details of these newly obtained specimens are given on pp. 421-424 of the present paper. 
Table 2. Occurrences of the Pacific ridley turtle classified by areas and seasons.

$\begin{array}{lcccc}\begin{array}{c}\text { Number of } \\ \text { records }\end{array} & \begin{array}{c}\text { East China Sea and } \\ \text { adjoining waters }\end{array} & \begin{array}{c}\text { Pacific coast } \\ \text { of Honshu }\end{array} & \begin{array}{c}\text { Japan Sea coast } \\ \text { of Honshu }\end{array} \\ \begin{array}{l}\text { Season of } \\ \begin{array}{l}\text { occurrence } \\ \text { (months) }\end{array}\end{array} & \begin{array}{c}\text { Summer to autumn } \\ \text { (VIII-IX) }\end{array} & \begin{array}{c}\text { Winter } \\ \text { (XII) }\end{array} & \begin{array}{c}\text { Autumn } \\ \text { (X-XI) }\end{array} & \begin{array}{c}\text { Winter } \\ \text { (XII-I) }\end{array}\end{array}$

main islands. The second is that there are seemingly two occurring seasons well separated from each other in the East China Sea while only one season is defined on either of the Pacific and Japan Sea coasts of Honshu Island of Japan, and that the occurring season on the Pacific coast follows immediately the major season in the

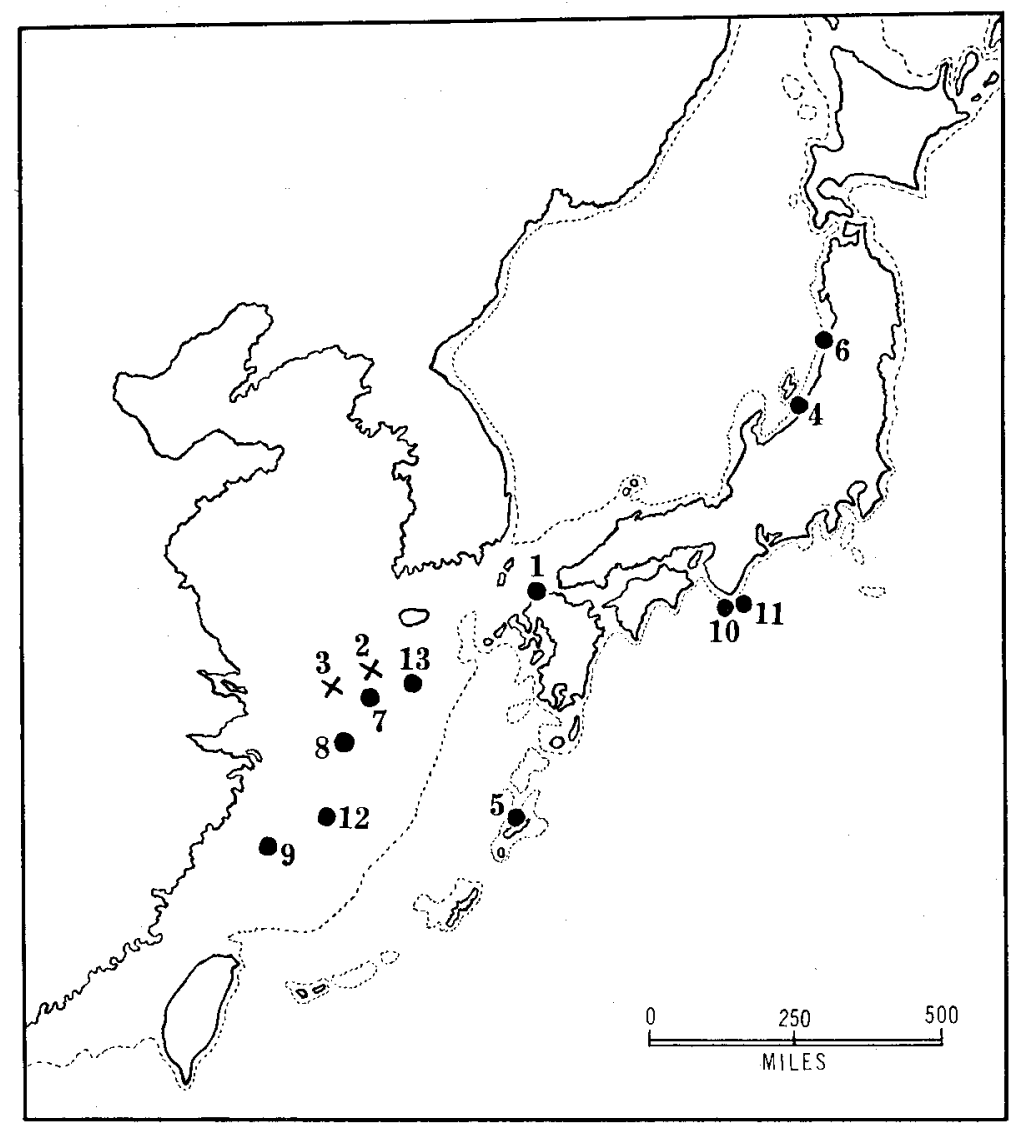

Fig. 1. Localities of the Pacific ridley turtle in Japanese and adjacent waters, 1957-1971. Circles indicate the localities the geographic positions of which are precisely known, while crosses indicate only approximate geographic positions. The Arabic figures show the record numbers in Table 1 . Broken lines are $150 \mathrm{~m}$ bathymetric contours roughly marking the edge of the continental shelf. 
East China Sea while that on the Japan Sea coast roughly coincides with the minor season in the East China Sea. The biological meanings implied by these will be discussed later. Anyhow, it can be said safely that the Pacific ridley turtle is rather rare in Japanese and adjacent waters except for the East China Sea.

The following considerations seem possible in regard to the migration or drift of the ridley turtle in the western Pacific waters:

1) The turtle may be extraneous to the Japanese waters, even to the East China Sea; its normal home ground or native area may be found in more southerly waters. The two seasons of occurrence in the East China Sea are considered to represent the periods of the northward drift from the native area and of the southward return to the southerly waters, respectively.

2) The turtle may start its northward drift in summer and enter the East Ghina Sea, giving rise to the major occurrence in summer to autumn, mainly August to September, there. This appears to well coincide with the seasonal hydrographic pattern in the East China Sea. The surface water temperature of the sea shows a marked seasonal change; in its central region the annual maximum $27-28^{\circ} \mathrm{C}$ is attained in August (Nagasaki Marine Observatory 1964). At the same time, the surface current system changes significantly with seasons; in summer, strong northward flows are generated by the southwest monsoon all over the sea as well as the South China Sea (KwAN 1957). No doubt these hydrographic features are favorable to the northward dispersal or drift of the turtle population.

3) Next, the drift may be done along three routes; a group of the population will follow the northward course in the East China Sea, the second group will be driven by the Kuroshio proper along the Pacific coasts of Japan, and the rest driven into the Japan Sea by the Tsushima current, a branch of the Kuroshio. The further drift of respective groups after they reach the destination of their northerly drift is supposed as follows. The first group will be driven back southward by the prevailing southerly surface currents developed in winter in the Yellow and East China Seas corresponding with the change of monsoon winds (KWAN 1957), possibly giving rise to the minor occurrence in the central area of the East China Sea. The second group, after being swept along the Pacific coast of Middle Honshu, will continue drifting along the Kuroshio into the oceanic areas of the Pacific. The last group, having entered the Japan Sea along the strong offshore branch of the Tsushima current, will reach the central area of the sea and there they will meet the outbreak of the northwest monsoon to be drifted southward, and finally reach the west coast of Honshu to be stranded. These may be the reasons why there is only a single occurring season on either of the Pacific and Japan Sea coasts of Honshu, while there are two seasons in the East China Sea.

The geographic range of the native or breeding place of the ridley turtle in the western Pacific cannot as yet be precisely delineated. This is largely due to the taxonomic confusion prevailed in most of the previous literature. However, some clues 
may be obtained by the present study. As seen in Fig. 1, all records of the Pacific ridley turtle in the East China Sea are situated within the continental shelf outside the main stream of the Kuroshio. This seems to favor the view that the turtles have not been driven into the East China Sea by the Kuroshio directly from the Philippine Sea, but instead they have been drifted there from the South China Sea with the northeast surface currents generated by the southwest monsoon in summer months (KwAN 1957; WyrtKi 1961) along the continent and passing through the Formosa Straits. This view seems better fitting the general belief that the turtles of the genus Lepidochelys are coastal inhabitants (Derantyagala 1939; Carr 1942). Further, the rare chance of the ridley turtle of being trapped and carried by oceanic currents such as the Kuroshio may explain much rarer occurrences of this sea turtle along the Pacific coast of Southern Japan than other tropical sea turtles, especially the green turtle Chelonia mydas which is only next to the Pacific ridley in abundance in tropical seas (Deraniyagala 1939; Pritchard 1969b).

Anyway, it seems likely that the ridley turtles appearing in the adjacent waters of Japan are originated in the South China Sea. In fact there are not a few reports mentioning or suggesting an abundant occurrence of this turtle in the South China Sea. For instance, Tirant (1885, as Caouana olivacea) and Bourret (1941, as Caretta olivacea) report the occurrence of the ridley turtle in Indo-China in such abundance that it is widely used in local tortoise-shell industries. The species appears also common on the South Ghina Sea coasts of Malay Peninsula and Borneo (Hendrickson 1958; Hendrickson \& Alfred 1961). Fang's (1934) statement that 'Caretta caretta' is abundant around the Paracel Islands in the South China Sea seems in all probability to concern with the ridley turtle.

Thus, at the present level of knowledge, it may be concluded that the ridley turtles found in the Japanese and adjacent waters are stray individuals from the population of the South China Sea, which are caught and subsequently carried northward into the East China Sea by the drift currents in the season of southwest monsoon, and some of which are further transported by the Kuroshio and its branch into the Japanese waters. This presumes that the ridley turtle is not necessarily confined to the coastal or lagoon waters where it is generally believed to dwell, but on occasions some individuals at least will go out into the offshore area affected by drifts or oceanic currents, even though it is less adapted to a pelagic life than the green turtle (cf. Zangerl \& TURnBull 1955). That the sea turtles of the genus Lepidochelys occasionally show a trait to venture into offshore waters and endure a long term drift seems to be justified: the Pacific ridley population in the Guyanas and the West Indies in the western Atlantic is considered to have been 'seeded' by gravid individuals drifted from West Africa (PRITCHARD 1969a) or some are still actually being transported as current-borne waifs from West Africa (CARR 1957); and it is a well known fact that the Atlantic congener L. kempi of the Gulf of Mexico is occasionally drifted to European waters across the North Atlantic (Deraniyagala 1938; Parker 1939; Hardy 1959). 
Nothing can be said definitely about the ultimate fate of those Pacific ridley turtles drifted into the northern waters around Japan; but it seems very likely that most of them will be lost in the barren oceanic waters of the central Pacific far east of Japan or perished by being stranded ashore on the west coast of Honshu.

Based on the considerations made above a supposed drift map of the Pacific ridley turtle in the Japanese and adjacent waters is given in Fig. 2.

Another point to be noted concerns the body size of the drifted turtles. The ten specimens measured by the present authors ranged from 21 to $62 \mathrm{~cm}$ in carapace length, eight of them falling within the range from 45 to $58 \mathrm{~cm}$ (Nishimura \& Hara 1967; and the newly obtained data). There is no report dealing with the sexual maturation in Lepidochelys olivacea in the western Pacific or Indian Ocean. According

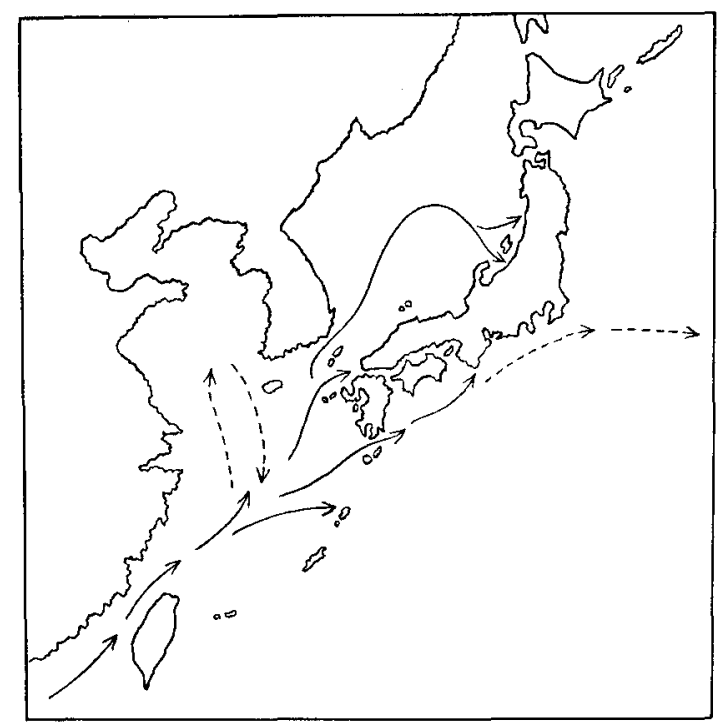

Fig. 2. Supposed drift routes of the Pacific ridley turtle in Japanese and adjacent waters.

Arrows indicate probable directions, while broken arrows indicate less definite directions, of the drift.

to Pritchard (1969a), however, the vast majority of female turtles from the Guyanas and Surinam in the western Atlantic reach maturity at the carapace length 26 to 28 inches $(66$ to $71 \mathrm{~cm})$, though some at the length as little as 23 inches $(58 \mathrm{~cm})$. If there is no substantial difference in the biological minimum between the western Pacific and western Atlantic populations, it may be assumed that the ridley turtles drifted to the Japanese waters are almost confined to the subadult stages. Such a situation is analogous to that reported previously for the hawksbill Eretmochelys imbricata migrating to the Japanese waters (Nishimura \& Yasuda 1967). 


\section{Details of the New Records}

Below are given the details of respective records of the Pacific ridley turtles newly reported in this paper.

\section{SPECIMENS CAUGHT IN THE EAST CHINA SEA IN 1958 (nos. 2 and 3 in Table 1)}

These two records were communicated by Dr. Satoshi Miтo (in litt., Aug. 14, 1967) to the first author. According to Dr. Mrтo, two unidentifiable sea turtles were brought respectively in summer and autumn, 1958, to the Fukuoka Aquarium where he was a curator at that time. They seemed resembling the loggerhead Caretta caretta to some degree but were clearly distinguished from the latter by their wider carapace colored grayish olive instead of reddish brown. They were also distinct in the number and arrangement of costal scutes, etc. However, at the paper by the first author reporting the occurrence of the ridley turtle in the Japanese waters (Nishimura \& Hara 1967) nearly ten years later, he readily realized that the turtles he had dealt with were actually this species. Both specimens, one small and the other medium-sized, were caught by motor trawlers in the East China Sea. In the aquarium they did
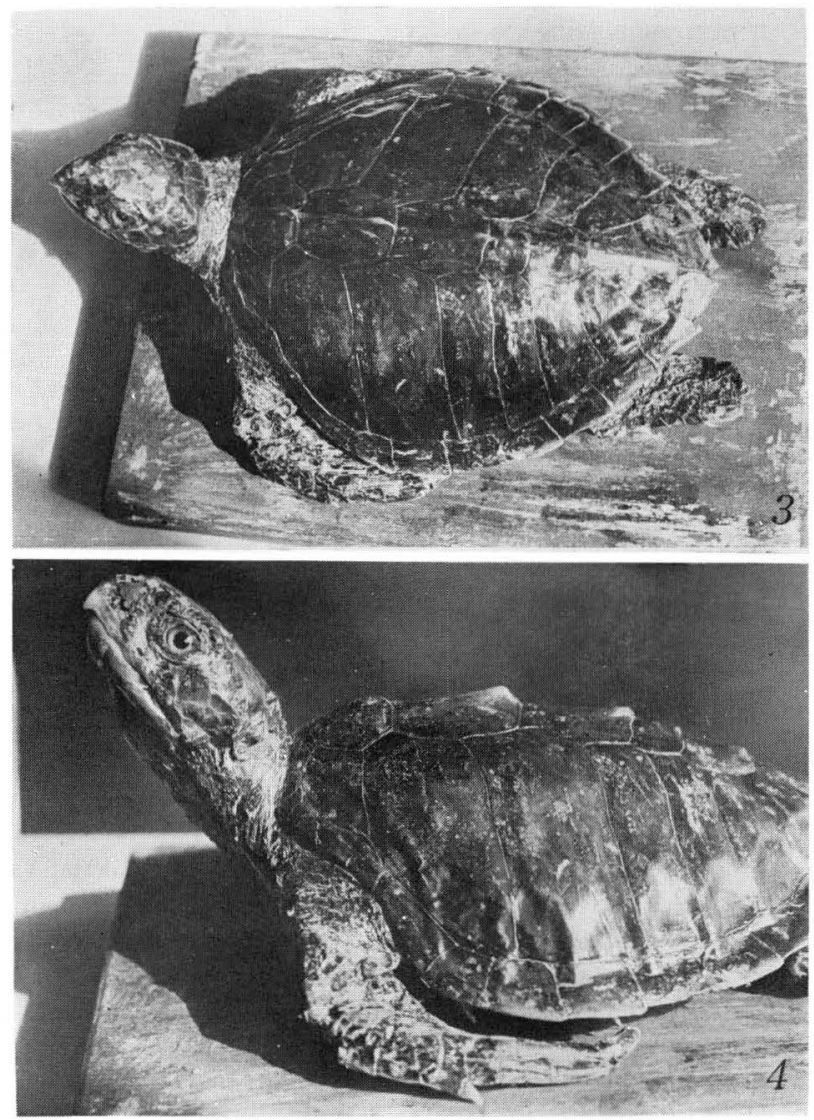

Figs. 3 and 4. Lepidochelys olivacea (Eschscholtz). Specimen no. 6 (stuffed), carapace length $21 \mathrm{~cm}$. Photo by S. Satake. 
not take any food and died within 20 days as he remembered. He put on record the exact localities and dates of capture together with the measurements and photographs. Much to regret, however, all these records have been lost after he retired from the aquarium.

\section{SPECIMEN CAUGHT AT AMAMI OSHIMA IN 1967 (no. 5 in Table 1)}

This specimen was reported on the Asahi Press (Kyushu edition, Oct. 10, 1967) as "A Poisonous Sea Turtle from Amami Oshima". According to the newspaper, the turtle, about $80 \mathrm{~cm}$ in body [i.e., total] length and $20 \mathrm{~kg}$ in weight, was caught near Yamato-mura, Amami Oshima, on Sept. 26 by a fisherman who was engaged in squid-angling. The turtle was brought to the Oshima Branch of the Kagoshima Prefectural Office, and because of its resemblance to the sea turtle which had been suspected as the source of severe food-poisoning reported from the Yayeyama Islands and Formosa ${ }^{6}$ ), it was sent to
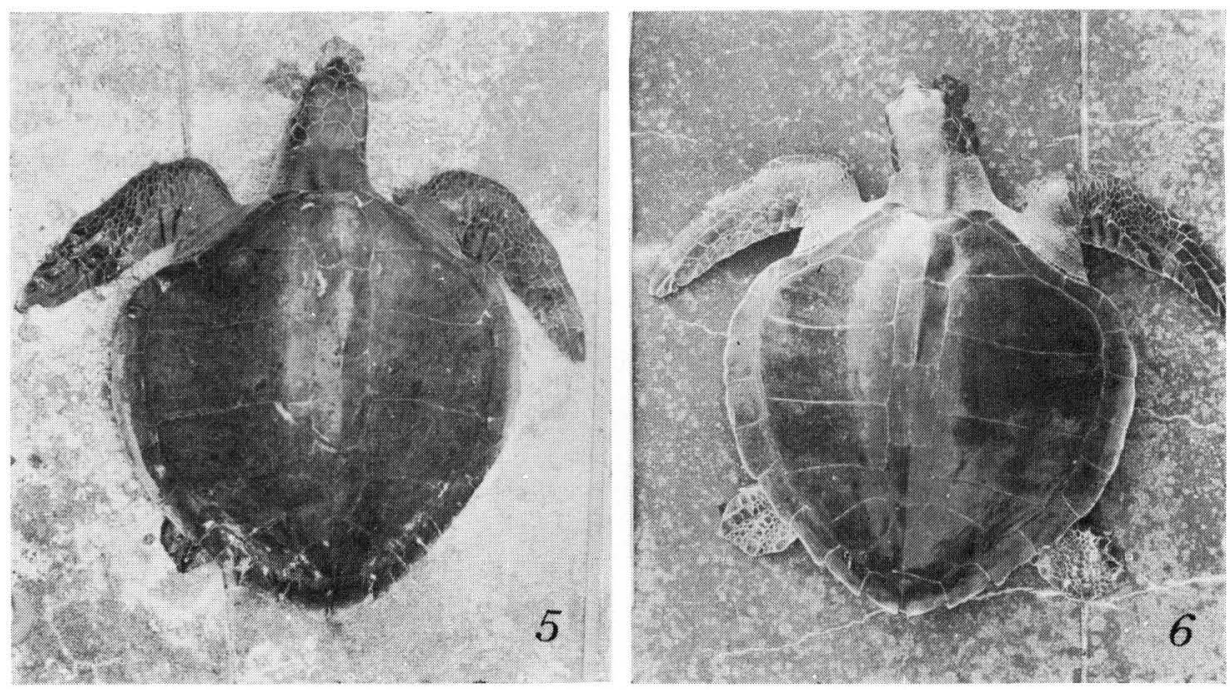

Figs. 5 and 6. Lepidochelys olivacea (Eschscholtz). 5 - Specimen no. 7 (living), carapace length $47 \mathrm{~cm}$; 6-Specimen no. 8 (living), carapace length $48 \mathrm{~cm}$.

Prof. Y. НАshimoto of the Tokyo University for a toxicological examination. The newspaper article is concluded with the statement that this was the first occurrence of this dangerous type of sea turtles in Amami Oshima.

By the description and photograph given on that paper, the present authors readily recognized that it was a Pacific ridley turtle; and it is listed here as a new record from the Japanese waters.

SPECIMEN CAUGHT ON THE COAST OF YAMAGATA PREFECTURE IN 1968 (no. 6 in Table 1; Figs. 3-4)

This specimen was stranded on the beach at Miyanoura village near Sakata, Yamagata Prefecture. It was found dead by Mr. Ichiro SATo of the village. The animal, first mis-identified as a hawksbill, was prepared to a stuffed specimen, which was checked by the last author of the present paper with the Pacific ridley turtle. The carapace was oval in outline and measured $19 \mathrm{~cm}$ wide by $21 \mathrm{~cm}$ long (percentage of width to length - 90.5), and its general coloration was olive. The vertebral scutes numbered 6 ,

6) The present authors suppose that they referred to the report by НАsнiмото et al. (April, 1967) on the food-poisoning by turtle meat in the Ryukyu Islands. In this interim report, Наsнiмото et al. summarized four cases of such food-poisoning, of which at least the one case occurred at the Pratas or Tungsha (東沙) Islands in the northern part of the South China Sea in June of 1952 was possibly due to the ridley turtle in the opinion of the first author of the present paper. 
the left costal 7, and the right costal 6 . The pattern of head shields was typical of Lepidochelys olivacea. The specimen still retained juvenile characters; for instance, a pronounced neural ridge was observed on the carapace, with the postero-median part of each vertebral scute, particularly that of the second scute, projecting backward as a marked prominence, though the costal ridges were already imperceptible. The arrangement of inframarginal scutes and the presence of inframarginal pores were not examined on account of some technial difficulties. The specimen is now kept by the last author at Sakata.

SPECIMENS CAUGHT IN THE EAST CHINA SEA IN 1969 (nos. 7 and 8 in Table 1; Figs. 5-6)

Both specimens were caught by two-boat motor trawlers belonging to the Nagasaki Branch of the Taiyo Fishing Co. while the trawlers were fishing demersal fishes in the East China Sea, and later brought to the Nagasaki Aquarium. They had the broad oval carapace with the neural ridge weakly developed and their head shield pattern was typical for Lepidochelys olivacea. The measurements and counts of these specimens are shown as follows:

Carapace width $(\mathrm{cm})$
Carapace length $(\mathrm{cm})$
$100 \times$ width/length
Body weight $(\mathrm{kg})$
Number of vertebrals
Number of costals
Number of larger inframarginals
Inframarginal pores

$\begin{array}{cc}\text { Specimen no. } 7 & \text { Specimen no. } 8 \\ 46 & 47 \\ 47 & 48 \\ 97.8 & 97.9 \\ 11 & 17 \\ 5 & 6 \\ l 6, r 5 & l 6, r 6 \\ l 3, r 3 & l 4, r 4 \\ \text { present } & \text { present }\end{array}$

Although Specimen no. 7 had somewhat smaller numbers of carapace scutes than the typical Pacific ridley as seen above, the identification leaves no doubt. This specimen also had a remarkable defect on its right hind limb, of which the portion distal to the knee had been lost possibly by a bite of such a large predator as shark (cf. Hendrickson 1958; Pritchard 1969a). The specimen was kept alive in the aquarium from August 30 to September 4 when it died probably from a bite wound inflicted by other sea turtles kept together in the same tank.

Specimen no. 8 has been raised in the aquarium since September 10, 1969 and is still well at present (February, 1972).

The stations where these turtles were captured are from 60 to $70 \mathrm{~m}$ deep. If the turtles were really caught on the sea bottom as it was considered so ${ }^{7}$, then these records will show that the Pacific ridley can dive as deep as $60-70 \mathrm{~m}$ in natural environments. See also the notes attached below to the description of the specimens nos. 9,12 and 13.

SPECIMENS CAUGHT IN THE EAST CHINA SEA IN 1971 (nos. 9, 12 and 13 in Table 1)

All these specimens were entangled in the net of a two-boat motor trawler belonging to the Izutsu Fishing Co., Nagasaki, and through the courtesy of Mr. Toshio Niry , the chief fisherman of the boat, were donated to the Nagasaki Aquarium where they have been raised since. The measurements and counts of these specimens are given as follows:

Carapace width $(\mathrm{cm})$
Carapace length $(\mathrm{cm})$
$100 \times$ width/length
Weight $(\mathrm{kg})$
Number of vertebrals
Number of costals
Number of larger inframarginals
Inframarginal pores

Specimen no. 9

53.4

55.2

96.8

20.2

7

$l 7, r 6$

$l 4, r 4$

present

$\begin{array}{cc}\text { Specimen no. } 12 & \text { Specimen no. } 13 \\ 55.5 & 50.2 \\ 58.0 & 53.0 \\ 95.8 & 94.7 \\ 26.3 & 20.8 \\ 7 & 6 \\ l 8, r 7 & l 6, r 6 \\ l 4, r 4 & l 4, r 4 \\ \text { present } & \text { present }\end{array}$

7) According to the officers of the trawl boats, it is quite unlikely that they were caught in mid-layers while the net was being drawn up. Rather, it is asserted that the turtles were in all probability entangled in the net on the sea bottom during the trawling operation lasting for three hours. 
The typically broad oval carapace and typical head shield pattern were seen in all specimens. The smallest (no. 13) was provided as yet with the rather prominent neural ridge on the carapace, while the largest (no. 12) with only the faintly developed one. Specimen no. 12 had a defect on its right hind limb, of which the distal third was lost similarly as in Specimen no. 7 mentioned previously.

The stations where Specimens nos. 9, 12 and 13 were captured are $80 \mathrm{~m}$ (est.), $99 \mathrm{~m}$ and $94 \mathrm{~m}$ (soundings by echogram) deep, respectively. And according to Mr. Nirya who collected them, it is believed that all these turtles were really entanged in the net on the sea bottom while the net was trawled. Taking the records of Specimens nos. 7 and 8, and perhaps also of nos. 2 and 3 together, this may strongly suggest a significant diving ability of the ridley turtle drifting at high seas. This should be evaluated in connection with the opinion of Deraniyagala (1939) that the Pacific ridley turtle is probably more of bottom dweller and less given to floating at the surface.

SPECIMENS CAUGHT OFF SHIONO-MISAKI IN 1971 (nos. 10 and 11 in Table 1; Figs. 7-8)

These specimens both entangled in the drift gill-net for flyingfish set in daytime in the surface layer were brought to the Marine Park Aquarium at Kushimoto. In both specimens, the carapace outline and head shield pattern were typical for Lepidochelys olivacea, and the neural ridge was faint (Specimen no. 10) or very faint (no. 11). The measurements and counts are shown below:

Carapace width $(\mathrm{cm})$
Carapace length $(\mathrm{cm})$
$100 \times$ width/length
Number of vertebrals
Number of costals
Number of larger inframarginals
Inframarginal pores

Carapace width $(\mathrm{cm})$

Number of vertebrals

Number of larger inframarginals

onal pores

$\begin{array}{cccc}\text { Specimen no. } 10 & & \text { Specimen no. } 11 \\ 56 & & 53 \\ 58 & & 55 \\ 96.6 & & 96.4 \\ 6 & & 6 \\ (\text { See Figs. } 7 \text { and } & 8) & \\ l 4, r 4 & & & l 4, r 4 \\ \text { present } & & & \text { present }\end{array}$

The fragmentation of costal scutes is irregular in these specimens, particularly in Specimen no. 10 (Figs. 7 and 8). Such irregularities in scute fragmentation are characteristically common in Lepidochelys olivacea, as noticed by Deraniyagal. (1939), Zangerl \& Turnbull (1955) and Pritchard (1969a).

Both specimens have been reared since in the Marine Park Aquarium at Kushimoto.
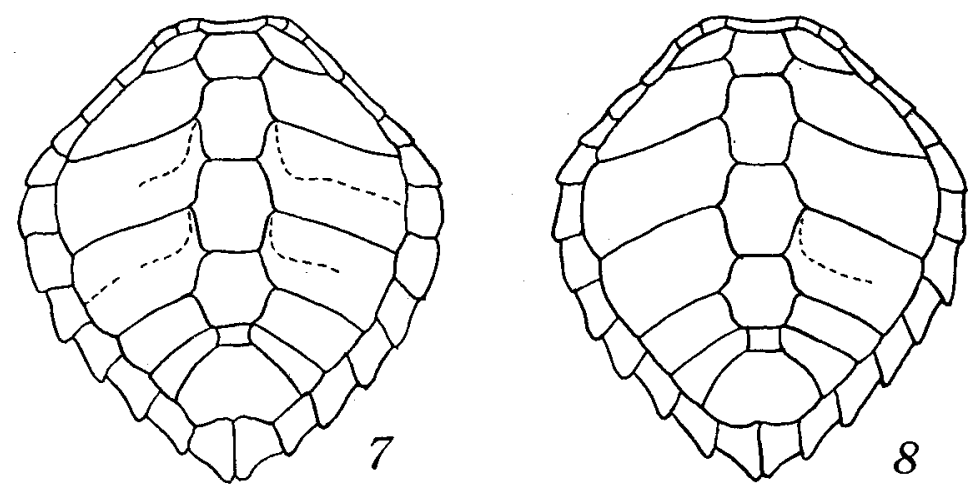

Figs. 7 and 8. Irregular fragmentation of costal scutes in Lepidochelys olivacea. 7-Specimen no. 10, carapace length $58 \mathrm{~cm} ; 8$ - Specimen no. 11, carapace length $55 \mathrm{~cm}$.

Broken lines indicate the supernumerary sutures, some of which are incomplete as shown above. 


\section{Summary and Conclusions}

1. The thirteen records of the Pacific ridley turtle Lepidochelys olivacea (Eschscholtz) known so far from the Japanese and adjacent waters are compiled and mapped (Table 1 and Fig. 1). Details of respective records newly obtained are given.

2. The size range of the recorded specimens are 21 to $62 \mathrm{~cm}$ in carapace length, and all of them are considered to belong to subadult stages.

3. The native area of the turtles drifted to the Japanese waters may be found in the South China Sea. As to the drift of the turtles to northerly waters, the surface currents generated by the southwest monsoon in the South and East China Seas in summer are considered to be primarily important, while the Kuroshio which carries them as far as the immediate surrounding waters of Japan may be of only a secondary importance.

4. The geographic position of their supposed native area and drift routes, together with their coastal nature, will account for the comparative rarity of this sea turtle in the Japanese waters.

5. Most of the turtles drifted to the Japanese waters will presumably be lost ultimately in the barren central Pacific or be perished by being stranded on the Japan Sea coast of Honshu Island.

6. The Pacific ridley turtle is considered really with a trend to the demersal life, and there are evidences suggesting that it can dive to the sea bottom as deep as $100 \mathrm{~m}$.

7. Two of the nine closely examined specimens had each a defect on a hind limb, presumably due to bite wounds. This may suggest a rather intense predation pressure inflicted upon the turtle population in their native area.

\section{REFERENCES}

Bourret, R. 1941. Les tortues de l'Indochine. Inst. Océanogr. l'Indochine, Note 38, 235 pp, pls. I-XLVII \& A-F (col.)

Garr, A. 1942. Notes on sea turtles. Proc. New England Zool. Club, vol. 21, pp. 1-16, 5 pls.

1957. Notes on the zoogeography of the Atlantic sea turtles of the genus Lepidochelys. Rev.

Biol. Trop., Costa Rica, vol. 5, pp. 45-61.

Deraniyagala, P. E. P. 1938. The Mexican loggerhead turtle in Europe. Nature, vol. 142, p. 540.

1939. The tetrapod reptiles of Ceylon. Vol. I. Testudinates and crocodilians. xxxii +412 pp., 24 pls. Colombo.

FANG, P. W. 1934. Notes on some chelonians of China. Sinensia, vol. 4, pp. 145-199.

Hardy, A. 1959. The open sea: its natural history. Part II. Fish and fisheries. xiv +322 pp., pls. $1-16$ (col.) \& I-XXXII. London.

Hashimoto, Y., Konosu, S. \& Yasumoto, T. 1967. [Studies on the ciguaterra caused by marine animals in the Ryukyu Islands. IV. Food-poisoning due to sea turtles]. 5 pp. Tokyo. (In Japanese; mimeo.)

Hendrickson, J. R. 1958. The green sea turtle, Chelonia mydas (Linn.) in Malaya and Sarawak. Proc. Zool. Soc. London, vol. 130, pp. 455-535, 10 pls.

- \& AlfReD, E. R. 1961. Nesting populations of sea turtles on the east coast of Malaya. Bull. Raffles Mus., Singapore, no. 26, pp. 190-196. 
Kwan, P.-H. 1957. A preliminary study on the relations between the surface currents and the winds along China coast. Oceanol. Limnol. Sinica, vol. 1, pp. 95-122. (In Chinese).

Nagasaki Marine Observatory 1964. The 10 day mean sea surface temperature of the East China Sea and the Yellow Sea, 1957-1962. Techn. Rep. Japan Meteorol. Agency, no. 31, pp. 1-105. (In Japanese).

Nishimura, S. \& Hara, K. 1967. The status of the sea turtles of the genera Caretta and Lepidochelys in Japanese waters (Testudinata: Cheloniidae). Acta Herpetol. Japon., vol. 2, pp. 31-35. (In Japanese).

\& YAsUdA, T. 1967. Records of the hawksbill turtle, Eretmochelys imbricata (LinNE), in the Japan Sea. Publ. Seto Mar. Biol. Lab., vol. 14, pp. 297-302.

Parker, H. W. 1939. Turtles stranded on the British coast 1938-1939. Proc. Linn. Soc. London, vol. 151, pp. 127-129.

Pritchard, P. C. H. 1969a. Sea turtles of the Guianas. Bull. Florida State Mus., Biol. Sci., vol. 13, pp. 85-140.

1969b. The survival status of ridley sea-turtles in American waters. Biol. Conservation, vol. 2, pp. 13-17.

Trrant, G. 1885. Notes sur les reptiles et les batraciens de la Cochinchine et du Cambodge: les tortues. Excurs. et Reconn., Saigon, tome 19, pp. 148-168.

Wyrtxi, K. 1961. Physical oceanography of the Southeast Asian waters. Naga Rep., vol. 2, pp. 1-195. ZANGerl, R. \& Turnbull, W. D. 1955. Procolpochelys grandaeva (LeIDy), an early carettine sea turtle. Fieldiana: Zoology, vol. 37, pp. 345-382, pls. 4-5. 